\title{
Bioflocculants Produced by Bacterial Isolates from Egyptian soil 1-Characterization and Application of Extracellular Bioflocculants and Nanoparticles for Treatment of River Nile Water
}

\author{
${ }^{1}$ Rawhia A. Arafa, ${ }^{2}$ Mahmoud N. El-Rouby, ${ }^{3}$ Hend A. Abass and \\ ${ }^{1}$ Zakia A. Abo El-khier \\ ${ }^{1}$ Botany and Microbiology Department, Faculty of Science, El Azhar University, Egypt \\ ${ }^{2}$ Virology and Immunology Unit, Cancer Biology Department, National Cancer Institute, Cairo University, \\ Egypt \\ ${ }^{3}$ Water Central Laboratories of Cairo, Egypt
}

\begin{abstract}
Bioflocculants are essentially polymers produced by microorganisms during their growth. In the present study, screening of twenty eight bacterial isolates producing flocculating substances were carried out .They were isolated from cultivated soil from El-Qanater El-Khayria, Egypt and the raw water samples tested [ River Nile water] have been collected from Ismailia Canal ( about $13 \mathrm{Km}^{2}$ from EL-Marge station for water treatment plant). From all isolates, two isolates that secret a largest amount of bioflocculant were selected. Based on16S rRNA gene sequencing and its morphological, physiobiochemical, characteristics, the isolates were identified as Bacillus cereus and Bacillus thuringiensis respectively. Maximum bioflocculant producing activity percent in water samples was affected by $\mathrm{pH}$ between 7-8 and at temperature rang $30-40^{\circ} \mathrm{C}$ and during growth period of strains from 72 to $96 \mathrm{~h}$. The biopolymer flocculants named $F Q-B 1$ and $F Q-B 2$, produced by Bacillus cereus and Bacillus thuringiensis were precipitated chemical elemental analyses and UV scan were achieved for investigating the purified bioflocculant. In two isolates bioflocculants, total carbohydrate content were $0.524 \mu \mathrm{g} / \mathrm{Im}(16.99 \%)$ and $0.321 \mu \mathrm{g} / \mathrm{lml}(15.27 \%)$ respectively, while the total protein content were 2.56 $\mu \mathrm{g} / 1 \mathrm{ml}(83.01 \%)$ and $1.78 \mu \mathrm{g} / \mathrm{lml}(84.73 \%)$ respectively. There are 18 types of mino acid were determined in both bioflocculants and the highest amino acid were Aspartic acid $(14.9 \mu \mathrm{g} / \mathrm{lml})$, and Leucine $(25.88 \mu \mathrm{g} / \mathrm{lml})$ . The present results anticipated that FQ-B1 and FQ-B2 had flocculating activity range from $75 \%$ to $76.3 \%$ and potential of application in raw water treatment, owing to their effective bioflocculation effective and harmlessness towards humans and the environment. Application of Silver $30 \mathrm{~nm} \&$ Gold $60 \mathrm{~nm}$ nanoparticles alone and in conjugation with bacterial bioflocculants exhibited efficient flocculation capabilities in the treatment of River Nile water. Using Gold and silver nanoparticles alone in raw water treatment was approximately similar to that obtained two bioflocculants FQ-Bland FQ-B2 and the conjugation of nanoparticles with bioflocculants ranged from (75 to 80\%). Transmission electron microscopy(TEM) observed images of the nanoparticles irregular circular in group or in linear shape, when conjugation with bioflocculants, nanoparticles trapping and converted to a large sponge structure, this refered to highly flocculating efficiency without addtion nanoparticles .
\end{abstract}

Key words: Bacillus cereus and Bacillus thuringiensis. , Bioflocculant, Flocculating activity, Water treatment, Gold and silver nanoparticles.

\section{Introduction}

The human attentions to the quality of drinking water go more than five thousand years. The purpose and limited extent have been used during the historical periods for treatment processes were boiling, filtration and sedimentation, and add some salts. In the eigheenth and nineteenth century a lot of serious attempts in the countries of Europe and Russia to advance the technology of water treatment. Famous salts that used in water and wastes sedimentation were aluminum sulfate and ferric chloride, and some assistance such as certain organic polymers can used to remove many organic compounds that cause a change in the taste and odor of water. The high turbidity observed with the use of aluminum sulfate as a coagulant can be due to the production of aluminum hydroxide precipitate in water. Besides being voluminous, the alum sludges are gelatinous, acidic , and difficult to dewater and dispose in the environment (Buthelezi et al., 2009) . Flocculants have been widely used in a variety of industrial processes, such as waste water treatment, the food and fermentation industries, drinking water purification, and industrial downstream processes (Shih et al., 2001 and Wu \& Ye, 2007). Flocculating agents are generally classified into three groups: (a) inorganic flocculants, such as aluminum sulfate and poly-aluminum chloride; (b) organic synthetic flocculants, such as poly-acrylamide derivatives and 
poly-ethylene-amine; (c) naturally occurring flocculants, such as chitosan, sodium alginate and bioflocculant (Salehizadeh \& Shojaosadati, 2001 and Zhang et al., 2007). Despite the effective flocculation performance and low cost of the synthetic chemical flocculants, their use has resulted in some health and environmental problems. For example, aluminum has been found to induce Alzheimer's disease (Arezoo, 2002). Furthermore, the acrylamide monomer is not only neurotoxic and carcinogenic, but also non-biodegradable in the nature. On the contrary, bioflocculants produced by microorganisms during their growth are safe and biodegradable polymers (Deng et al., 2003). Many bioflocculant-producing micro-organisms including bacteria, fungi and actinomyces have been reported to produce extracellular polymeric substances, such as polysaccharides, functional proteins and glycoprotein's, which function as bioflocculant (Kumar et al., 2004). Nanotechnology is an emerging and fast-growing technology. Currently, there are more than 1,317 nanotechnology-based products on the market. Silver nanoparticles account for more than $23 \%$ of all nano-products . The extensive application of the silver nanoparticle (AgNP) results in their inevitable release into the environment. Silver nanoparticles are known as excellent antimicrobial agents, and therefore they could be used as alternative disinfectant agents . On the other hand, released silver nanoparticles could pose a threat to naturally occurring microorganisms (Zhang, 2013). So that this study deals with the screening and isolation of bioflocculant producing bacteria from cultivated clay soil . Identification for the selected isolates by morphological, biochemical, physiological methods as well as 16s rRNA was carried out. Characterization of the produced bioflocculants was done. Application of silver/gold nanoparticles for water treatment alone and in conjugation with tested bioflocculants was assessed taken in consideration aluminum sulfate in our comparison .

\section{Materials and Methods}

\section{1- Sample collection:}

Twenty eight bacterial strains were isolated from cultivated clay soil from El-Qanater El-Khayria, Egypt. Water samples collected from Ismailia Canal (about $13 \mathrm{Km} 2$ from EL-Marge station for water treatment plant) for detection of bio-flocculating activity. All containers used for sampling were been cleaned and rinsed following trace metal protocols and were sterile.

2- Screening and identification of highly bioflocculant-producing bacteria: Isolation of bioflocculantproducing bacteria was carried out using nutrient agar medium with composition of glucose 10g; yeast extracts $5 \mathrm{~g}$; peptone $5 \mathrm{~g} ; \mathrm{NaCl} 1 \mathrm{~g}$ and agar $15 \mathrm{~g} / 1$ of distilled water at $\mathrm{pH} 7+0.2$ and incubated at $37^{\circ} \mathrm{C}$ for $24 \mathrm{~h}$ (Chen and Zhao, 2003). Bioflocculant producing bacteria were originally screened based on colony morphology (mucoid ,ropy and their color). Purified isolates were inoculated into $50 \mathrm{ml}$ of bioflocculant production medium with composition of starch $20 \mathrm{~g}$, yeast extracts $3 \mathrm{~g}, \mathrm{CaCO}_{3} 5 \mathrm{~g} ; \mathrm{K}_{2} \mathrm{HPO}_{4} 0.5 \mathrm{~g} ; \mathrm{MgSO}_{4} \cdot 7 \mathrm{H}_{2} \mathrm{O} 0.2 \mathrm{~g} ; \mathrm{NaCl}$ $0.2 \mathrm{~g} ; \mathrm{CaSO}_{4} 0.1 \mathrm{~g} ; \mathrm{MnSO}_{4} .7 \mathrm{H}_{2} \mathrm{O}$ traces; $\mathrm{FeSO}_{4} .7 \mathrm{H}_{2} \mathrm{O} 0.01 \mathrm{~g} ; \mathrm{Na}_{2} \mathrm{MoCu} .2 \mathrm{H}_{2} \mathrm{O}$ traces and $15 \mathrm{~g}$ of agar, completed to $1000 \mathrm{ml}$ with distilled water (Desouky et al., 2008), $\mathrm{pH}$ was adjusted at 7.2 and incubated at $37^{\circ} \mathrm{C}$ for 3 days. After incubation period cultures broth was centrifuged at $(8000 \mathrm{xg}, 15 \mathrm{~min}$.) to separate the cells and tested for flocculating activity every $72 \mathrm{~h}$. Finally, the isolates with high and stable flocculating activities were selected for further studies.

\section{3 - Determination of flocculating activity by Jar or clarifier testing (Gregory, 2006).}

Jar or clarifier test is a major method of simulating a full-scale water treatment process, providing system operators a reasonable idea of the way treatment chemical will behave and operate with a particular type of raw water. The absorbance of supernatant and blank control without bioflocculant was measured at $550 \mathrm{~nm}$ (as $\mathrm{OD}_{550}$ and $\mathrm{OD}$ blank, respectively) with spectrophotometer. The flocculating activity (í) was defined and calculated as follows: $(\dot{\eta})=\left(\mathrm{OD}_{\text {blank }}-\mathrm{OD}_{550}\right) / \mathrm{OD}_{\text {blank }} \mathrm{x} 100$ (Gregory, 2006).

\section{4- Separation and purification of Bioflocculant (Peiyong et al., 2004):}

Purified isolates were inoculated into $50 \mathrm{ml}$ of bioflocculant production medium. After incubation period ( 3 days), the culture broth was diluted with two volumes of distilled water and centrifuged at 4,000xg for $15 \mathrm{~min}$. The supernatant was poured into three volumes of acetone $(1: 3)$ and added three times to precipitate the biopolymer flocculant. The precipitate was collected by centrifugation at $8,000 \mathrm{x} \mathrm{g}$ for $20 \mathrm{~min}$. then washed by ether. The crude obtained was dialyzed at $4^{\circ} \mathrm{C}$ overnight in de-ionized water and vacuum-dried over night in a desiccator to obtain pure bioflocculants named FQ-B1 and FQ-B2 and re-dissolved in distilled water.

\section{5 -Determination \& characterization of bioflocculants FQ-B1 and FQ-B2:}

Elemental analyses were achieved with UV Scan for measuring total carbohydrate contents. Total soluble carbohydrate concentration can be determined by Ultraviolet-Visible Range Spectroscopy (UV-Vis) at wavelength 485 and expressed as the glucose equivalent. This method is simple, fast, accurate, and specific to carbohydrate methodology by Ammar (2013). Protein concentration was determined by the using bovine serum 
albumin as a standard protein, the color was read at $750 \mathrm{~nm}$ using spectrophotometer according to Bradford method Bradford (1976). Amino acid moiety in the flocculant proteins were determined by amino acid autoanalyzer. This experiment was done in National Center for Radiation and Technology, Cairo, Egypt .

\section{6 -Optimization of cultural parameters on bioflocculant activity:}

Several factors affecting on bioflocculant activity, within the intervals of 1 day up to 12 days, were studied as follows:.1- Effect of different incubation temperature range of $\left(25-60^{\circ} \mathrm{C}\right)$. 2- The effect of different $\mathrm{pH}$ values were adjusted at different $\mathrm{pH}$ between (6.0 to10.5). 3- Effect of different incubation period from (12h.-192h). 4-Effect of various concentrations of mineral salt $\mathrm{CaCO}_{3}, \mathrm{FeCl}_{3}, \mathrm{FeCl}_{2}, \mathrm{MnSO}_{4}, \mathrm{CuCl}_{2}, \mathrm{MgCl}_{2}$, and $(\mathrm{NH} 4)_{2} \mathrm{SO}_{4}$. 5- Effect of different nitrogen sources as yeast extract, urea, peptone beef extract and $\left(\mathrm{NH}_{4}\right)_{2} \mathrm{SO}_{4}$ were used. 6- Effect of different carbon sources as glucose, sucrose, fructose, lactose and starch .

\section{7- Testing bioflocculants activity in comparison with aluminum sulfate:}

The comparison between tested water treated by the investigated bioflocculants and those treated with aluminum sulfate were estimated by Jar test. Different factors have been tested in this experiment, such as: turbidity, $\mathrm{pH}$, total dissolved salt (TDS), ammonia, nitrite, nitrate, total hardness, amount of $\mathrm{Ca}^{+2}, \mathrm{Mn}^{+2}, \mathrm{Fe}^{+3}$, $\mathrm{Fe}^{+2}, \mathrm{Mg}^{+2}, \mathrm{Al}$, total count of algae, total bacteria and total coliform .

\section{8 -Identification of bioflocculant producing bacteria:}

8-a)-The morphological, biochemical, physiological characteristics of the selected strains using Cowan and Steel's, 1977 methodology and were identified according to Bergey's Manual of Systematic Bacteriology (Sneath, 1986 and Hotle et al., 1994).

\section{8-b)-16s sequence determination and phylogenetic characters:}

Molecular techniques including genomic DNA extraction by Sambrook et al.(1989), PCR mediated amplification of the $16 \mathrm{~S}$ ribosomal DNA, purification of PCR products and sequencing of the PCR products for the isolates under study were performed in VACSERA, El-Agoza, Egypt.

\section{8-c)-Amplification and sequencing of the 16S rRNA gene:}

The 16S rRNA gene was amplified by polymerase chain reaction (PCR) using eubacterial universal primers. That was $104 \mathrm{~F}$ with the sequence

5'-GGACGGGTGAGTAACACGTG-3' and R1492 with the sequence

5'-CACGTGTTACTCACCCGTCC-3' (Rainey et al., 1996). The PCR mixture consisted of 30

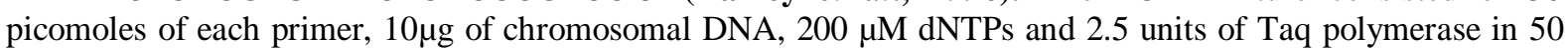
$\mu \mathrm{l}$ of polymerase buffer. The PCR was carried out for 30 cycles at $94{ }^{\circ} \mathrm{C}$ for $1 \mathrm{~min}, 55^{\circ} \mathrm{C}$ for $1 \mathrm{~min}$ and $72{ }^{\circ} \mathrm{C}$ for 2 min. After completion, PCR product was purified using PCR purification kit (Qiagen, Germany). phylogenetic analysis (Yoon $\boldsymbol{e t} \boldsymbol{a l}$., 2000) by DNA sequences were obtained using an ABI PRISM 3700 DNA sequencer and ABI PRISM Big Dye Terminator Cycle Sequencing.

\section{8-d)-Cluster Analyses for Bacillus cereus, Bacillus thuringiensis by DNA sequence similarities and} phylogenetic analysis:

Sequence data were analyzed in the GenBank database by using the BLAST program available on the National Center for Biotechnology Information website (www.ncbi.nlm.nih.gov) . The unknown sequences were compared to all of the sequences in the database to assess the DNA similarities (Claudio, et al., 2002) . For studying phylogenetic relationships of the investigated isolates with other similar reference strains depending on morphological biochemical, physiological characteristics and phylogenetic analysis viz. Bacillus cereus, Bacillus thuringiensis TS2. Bacillus spRsr, Bacillus spBB61, Bacillus cereus strain DBT3SC1, Bacillus cereus strain SS07. Bacillus cereus strain KVP109, Bacillus cereus strain KVP105, Bacillus anthracis strain KS-1 and Bacillus sp GS18 and Bacillus thuringiensis B4 (1) were evaluated by using statistical cluster analysis with joining (tree clustering) being the clustering method. The phenotypic characters were amalgamated by un-weighted pair-group average method analysis (UPGAMA). However, complete linkage was the method for studying character profiles using statistics for windows, release 4.5f, and state Soft, Inc. 1993 software. Euclidean distances (similarity matrix) were used as the distance metric in both as well as dice coefficient as the calculation method. 
9 ) preparation and characterization of Silver and Gold Nano-particles

(Pradeep and Anshup, 2009):

9-a) Determination using Ultraviolet-Visible Range Spectroscopy (UV-Vis) (Ammar, (2013):

The wavelength of nano-particles can be determined by Ultraviolet-Visible Range Spectroscopy (UV-Vis) at wavelength $\mathbf{4 2 1}$ w.v. for silver and $\mathbf{5 2 7}$ w.v. for gold nano-particles.

9-b)Transmission electron microscopy (TEM) images of silver and gold nanoparticles :

This method was used for magnified of bacterial bioflocculant, silver and gold nanoparticles. The method was done according to John ( 2010) .

9-c) Application of Silver \& Gold Nanoparticles with Bacterial bioflocculants FQ-B1 and FQ-B2, for water treatment (Farland, et al., 2004) and (Gang, 2013):

This experiment was carried out to investigate the application of nanoparticles with biofloccul-ants for water treatment. Each one of the tested bioflocculants (FQB1, FQB2) was dissolved in $1 \mathrm{ml}$ phosphate buffer saline and mixed with $1 \mathrm{ml}$ of nano-particle solutions and then added to raw water in Jar test for determination the effect of silver and gold nanoparticles that conjugated with bacterial bioflocculants for water treatment, also for determine the activity of gold and silver nanoparticles alone by using Jar or Clarifier test. (Gang 2013)

\section{0)-Statistical analysis:}

Results were analyzed statistically using student's t-test. Values of $\mathrm{p}<0.05$ were considered statically significant. All data in the text and tables are expressed as a percentage of dark control standard error (SEM) of at least three samples; experiments were repeated 3 times. The statistical analysis was carried out by Graphpad® prism soft ware (USA).

\section{Results}

1-Screening of bioflocculant with slimy or mucoid appearance producing bacteria:

A total of twenty eight bacterial isolates with slimy or mucoid appearance were isolated from cultivated clay soil from El-Qanater El-Khayria, Egypt . These isolates were purified and screened for their flocculating activity using water samples collected from Ismailia Canal (about $13 \mathrm{Km}^{2}$ EL-Marge station for water treatment plant) based on the decreasing turbidity. Among them, two strains causing the lowest turbidity after $72 \mathrm{~h}$ (Table 1) were selected for further studies. These selected strains were designated as B1 \& B2 on preliminary test and exhibited turbidity values $3.21,4.3$ respectively compared to control (raw water turbidity) 7.8 NTU (National Turbidity Unit) . The bioflocculants produced by the selected isolates B1 \& B2 were named FQ-B1 and FQ-B2 respectively .

(Table 1) : Preliminary test for determination the flocculants activity produced by different bacterial isolates on raw water using jar test .

\begin{tabular}{|l|l|l|l|}
\hline Organism & Turbidity & Organism & Turbidity \\
\hline $\begin{array}{l}\text { Bacterial isolates } \\
\text { from soil }\end{array}$ & mean & $\begin{array}{l}\text { Bacterial isolates from } \\
\text { soil }\end{array}$ & mean \\
\hline 1 & 7 & \multicolumn{1}{|c|}{$\mathbf{1 5}(\mathbf{B 1})$} & $\mathbf{3 . 2 1}$ \\
\hline 2 & 6.4 & $\mathbf{1 6}(\mathbf{B 2})$ & $\mathbf{4 . 3}$ \\
\hline 3 & 6.5 & 17 & 6.9 \\
\hline 4 & 4.9 & 18 & 7 \\
\hline 5 & 4.81 & 19 & 6.9 \\
\hline 6 & 4.9 & 20 & 7.36 \\
\hline 7 & 4.8 & 21 & 7.56 \\
\hline 8 & 5.3 & 22 & 6.97 \\
\hline 9 & 5 & 23 & 7.3 \\
\hline 10 & 7.8 & 24 & 7.8 \\
\hline 11 & 7.2 & 25 & 7.49 \\
\hline 12 & 5.6 & 26 & 7.8 \\
\hline 13 & 7.6 & 27 & 7.06 \\
\hline 14 & 7.8 & 28 & 7.7 \\
\hline
\end{tabular}

Turbidity of raw water (Control): is 7.8 NTU (National Turbidity Unit)

\section{2-Effect of different cultural parameters on flocculants FQ-B1 and FQ-B2 Production:}

Maximum flocculating activity was affected by different cultural parameters (Figs. 1, 2, 3, 4, 5,6,7and 8). The maximum values of FQ-B1 and FQ-B2 were between 7-8 of both investi-gated strains . The favorable temperature ranging from $30-45^{\circ} \mathrm{C}$ decreased obviously beyond $55^{\circ} \mathrm{C}$ for both studied strains . The production of flocculants FQ-B1 and FQ-B2 from two strains also affected by the presence of some cations . It was maximum in the presence of $\mathrm{Ca}^{+2}, \mathrm{Mg}^{+3}, \mathrm{Fe}^{+3}$ and $\mathrm{Mn}^{+2}$. The flocculating activity of two strains reached its peak in at the 
end of growth phase and at the beginning of stationary phase (72h.), the data obtained indicated also that , flocculating rate and the growth of the two strains increased with increasing cultivation time till forth day. Among the organic nitrogen source tested, urea, peptone and yeast extract were appear favorable for both cell growth and flocculating production of the two tested strains. Also glucose, fructose and starch were appeared favorable for both tested strains. On the other hand the best concentration of $\mathbf{B} 1$ bioflocculant on turbidity of raw water was $2.56 \mu \mathrm{g} / 1 \mathrm{~m}$ and $1.78 \mu \mathrm{g} / 1 \mathrm{ml}$ for $\mathbf{B 2}$ Effect of bioflocculant dosege : Figs $\mathbf{7}$ and 8 showed the relationship between the concentration of the bioflocculants and thier activities. The maximum flocculating activity $(80 \%)$ was achieved of bioflocculant dosage of $2 \mathrm{~m} / \mathrm{L}$ for $\mathbf{B 1}$ isolate and it was around $76.2 \%$ when the flocculants concentration was adjusted to $4 \mathrm{ml} / \mathrm{L}$. for $\mathbf{B} 2$ isolate .

\section{3-Identification of strains:}

The morphological character of $\mathbf{B} 1$ colony strain was circle, mucoid, ropy and brown in color while $\mathbf{B} \mathbf{2}$ was circle, mucoid, ropy and white in color. From these characteristics and physiological, biochemical characteristics listed in (Table 2, Figs. 9 -a and -b ), the investigated bacterial isolates B1 and B2 resemble Bacillus cereus and Bacillus thuringiensis respectively according to Bergey's Manual of Systematic Bacteriology ( Sneath, 1986 and Hotle et al., 1994 ) . At the same time the 16s rDNA of these strains were sequenced following PCR amplification.The strain B2 showed obvious similarity within the cluster of Bacillus sp. So according to morphological, physiobiochemical characterastics and 16S rDNA and in comparison with those in other database in GenBank the strains B1 shared approximately 50\% identity with Bacillus cereus and B2 approximately 100\% with Bacillus thuringiensis.

(Fig 1): Effect of different pH values on B1and B2 bioflocculants production

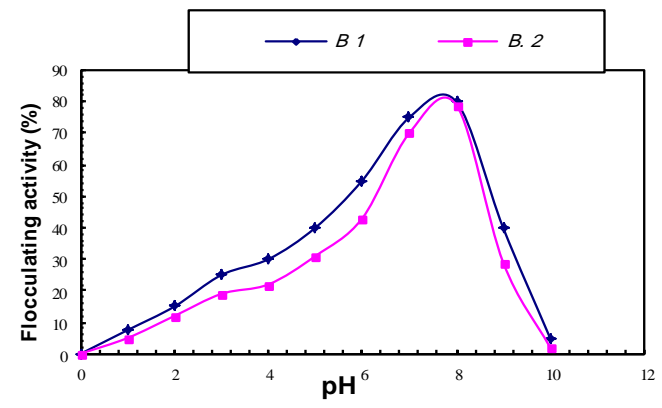

Fig (3) Effect of the presence of metal ions in

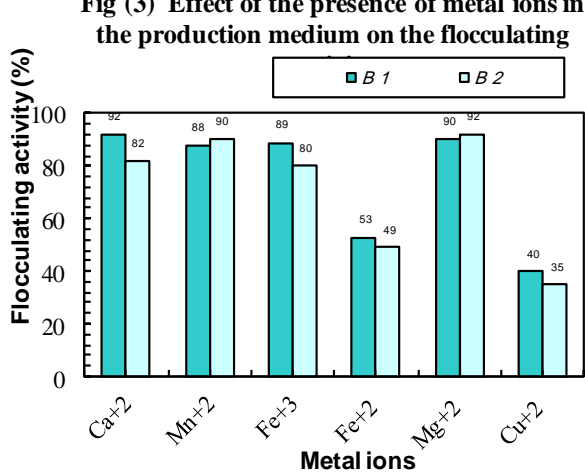

(Fig 2) Effect of temperature on activity of both isolates B1\&B2 bioflocculants production

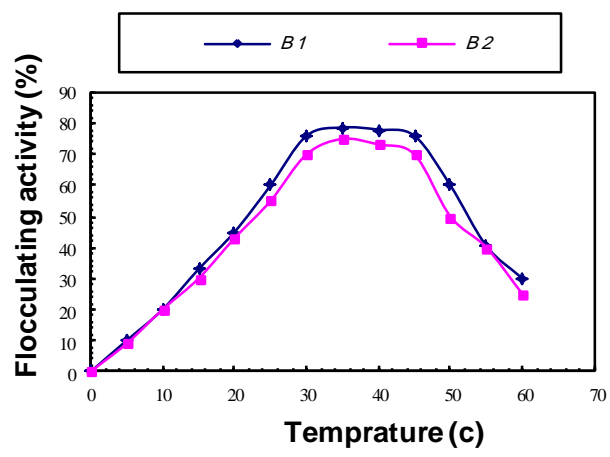

(Fig 4) Activity percent of flocculant isolats at different incubation periods

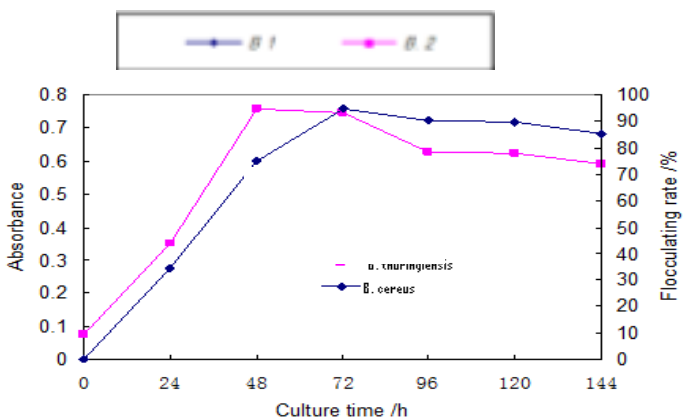


(Fig 5): Effect of different nitrogen sources on isolates B1\&B2 flocculent productions.

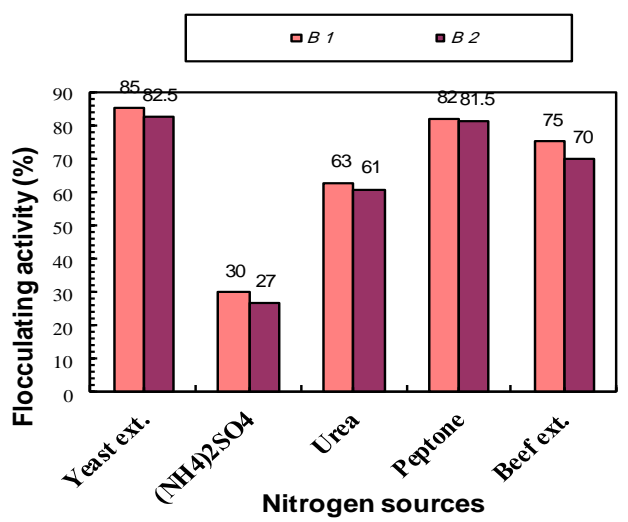

(Fig 7): Effect of different concentrations of $B 1$ in bioflocculant $\mathrm{FQ}-\mathrm{B} 1$ on turbidity of raw water

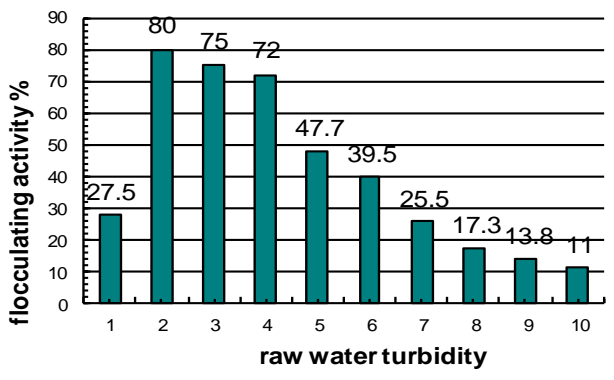

(Fig 6): Effect of different carbon on both isolates $\mathrm{B} 1 \& \mathrm{~B} 2$ flocculent production

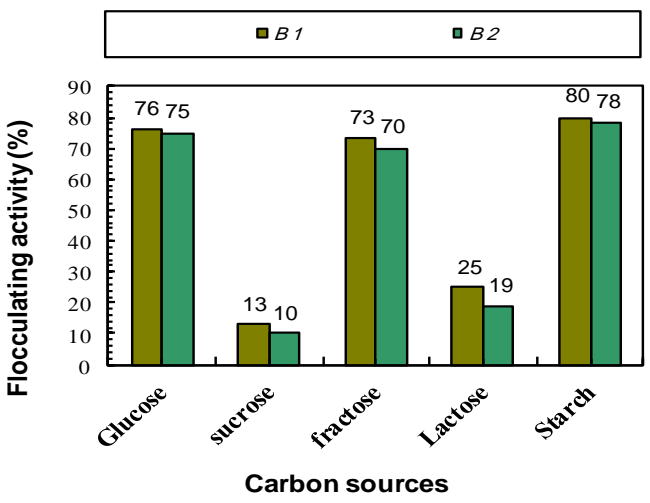

(Fig 8): Effect of different concentrations of B2 bioflocculant FQ-B2 on turbidity of raw water .

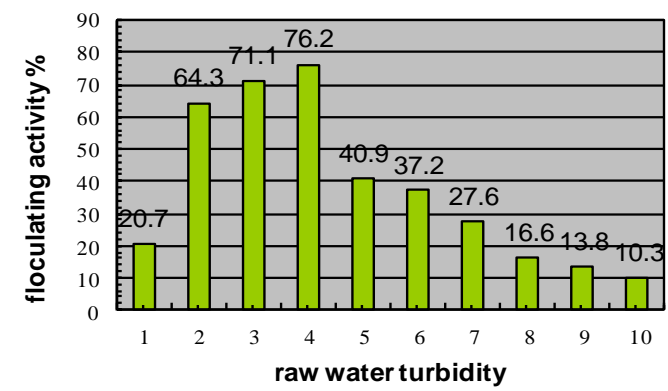

(Table2): A-physiobiochemical characteristics of Bacillus cereus \& Bacillus thuringiensis:

\begin{tabular}{|c|c|c|}
\hline physiobiochemical test & Bacillus cereus & Bacillus thuringiensis \\
\hline Motility & Motile & Motile \\
\hline Growth areation & Facultative anaerobic & Facultative anaerobic \\
\hline Gram's reaction & + ve & + ve \\
\hline KOH & $+\mathrm{ve}$ & $+\mathrm{ve}$ \\
\hline Colony colour & $\begin{array}{l}\text { circle, mucoid, ropy and } \\
\text { brown }\end{array}$ & $\begin{array}{l}\text { circle, mucoid, ropy and white } \\
\text { in color }\end{array}$ \\
\hline Shape & Rod shape & Rod shape \\
\hline Lengh um & 3-5 & $>1$ \\
\hline Endospores producer & + ve & Formed outside \\
\hline Lactate & $+\mathrm{ve}$ & - ve \\
\hline $\begin{array}{c}\text { Growth at pH } 5.7 \\
6.8\end{array}$ & $\begin{array}{l}+\mathrm{ve} \\
+\mathrm{ve}\end{array}$ & $\begin{array}{l}+\mathrm{ve} \\
+\mathrm{ve}\end{array}$ \\
\hline Strick anaeorobic & - ve & - ve \\
\hline Sufate activity reduced to sulfid & - ve & - ve \\
\hline Oxidase & - ve & + ve \\
\hline succinate & $+\mathrm{ve}$ & $-\mathrm{ve}$ \\
\hline $\begin{array}{rr}\text { Temperature range } & 30^{\circ} \mathrm{C} \\
40^{\circ} \mathrm{C} \\
65^{\circ} \mathrm{C} \\
\end{array}$ & $\begin{array}{l}+ \text { ve } \\
- \text { ve } \\
- \text { ve } \\
\end{array}$ & $\begin{array}{l}+v e \\
+ \text { ve } \\
- \text { ve }\end{array}$ \\
\hline Utiling of citrat & $+\mathrm{ve}$ & $+\mathrm{ve}$ \\
\hline Casein hydrolysis & $+\mathrm{ve}$ & $+\mathrm{ve}$ \\
\hline Gelatin hydrolysis & $+\mathrm{ve}$ & $+\mathrm{ve}$ \\
\hline Starch hydrolysis & $+\mathrm{ve}$ & $+\mathrm{ve}$ \\
\hline Catalase test & $+\mathrm{ve}$ & $+\mathrm{ve}$ \\
\hline Indole test & - ve & - ve \\
\hline Vogas-preskaure test & $+\mathrm{ve}$ & $+\mathrm{ve}$ \\
\hline Urease test & $+\mathrm{ve}$ & $+\mathrm{ve}$ \\
\hline Nitrate reduction & $+\mathrm{ve}$ & $+\mathrm{ve}$ \\
\hline
\end{tabular}




\begin{tabular}{|l|l|l|}
\hline Carbohydrate fermentation & \\
Glucose & $+\mathrm{ve}$ & $+\mathrm{ve}$ \\
Sucrose & $+\mathrm{ve}$ & $+\mathrm{ve}$ \\
Fructose & $+\mathrm{ve}$ & $+\mathrm{ve}$ \\
Sucrose & $+\mathrm{ve}$ & $+\mathrm{ve}$ \\
Maltose & $+\mathrm{ve}$ & $+\mathrm{ve}$ \\
Xylose & $-\mathrm{ve}$ & $-\mathrm{ve}$ \\
Manitole & $-\mathrm{ve}$ & $-\mathrm{ve}$ \\
glycerol & $+\mathrm{ve}$ & $-\mathrm{ve}$ \\
\hline
\end{tabular}

\section{4-Characteristics \& composition analysis of bioflocculant:}

Chemical elemental analyses were achieved with UV Scan for analyses of the purified bioflocculant from broth culture (Glycoprotein's), total carbohydrate content of Bacillus cereus and Bacillus thuringiensis were $0.524 \mu \mathrm{g} / 1 \mathrm{~m}(16.99 \%)$ and $0.321 \mu \mathrm{g} / 1 \mathrm{ml}(15.27 \%)$ respectively. While the total protein content in both isolate $2.56 \mu \mathrm{g} / 1 \mathrm{~m}(83.01)$ and $1.78 \mu \mathrm{g} / 1 \mathrm{ml}(84.73)$ respectively. Amino acid analysis was determined that there are 18 types of amino acids found in bioflocculants in both isolates. In Bacillus cereus and Bacillus thuringiensis bioflocculant soluble protein found that Leucine $(25.88 \mu \mathrm{g} / 1 \mathrm{ml})$ and Aspartic acid $(14.9 \mu \mathrm{g} / 1 \mathrm{ml})$ were highly amino acid concentration respectively as shown in Table (3) and Fig. (10).

(3-a) Phylogenetic tree showing the relationships among the selected isolates and published 16S rDNA sequences (a) for $\mathrm{B} 1$ and (b) for $\mathrm{B} 2$

(Fig. 9 - a): Phylogenetic tree of B. cereus:

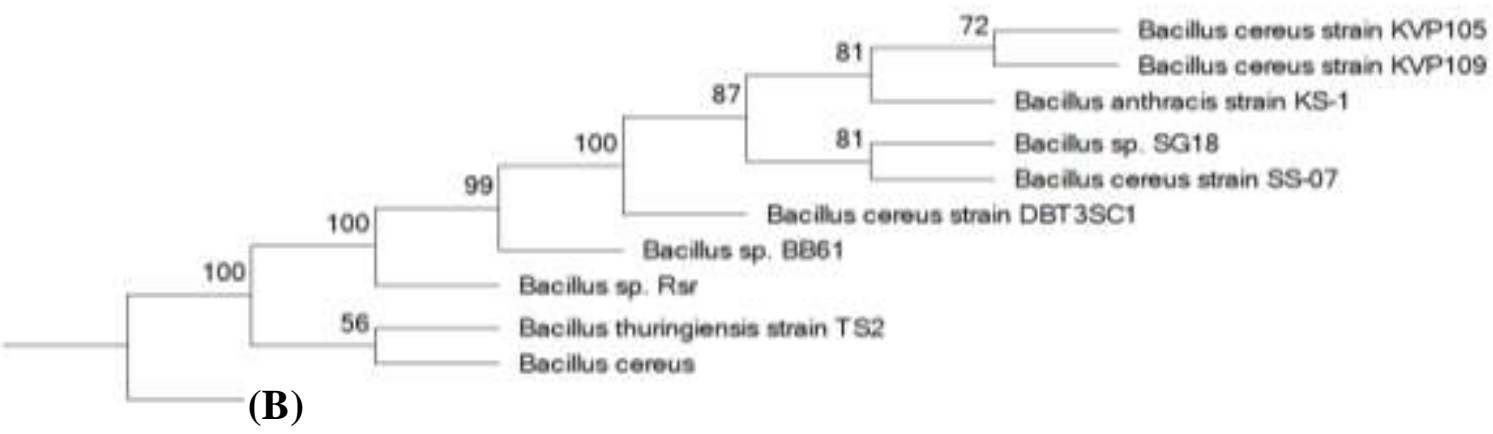

(Fig. 9-b): Phylogenetic tree of B. thuringiensis

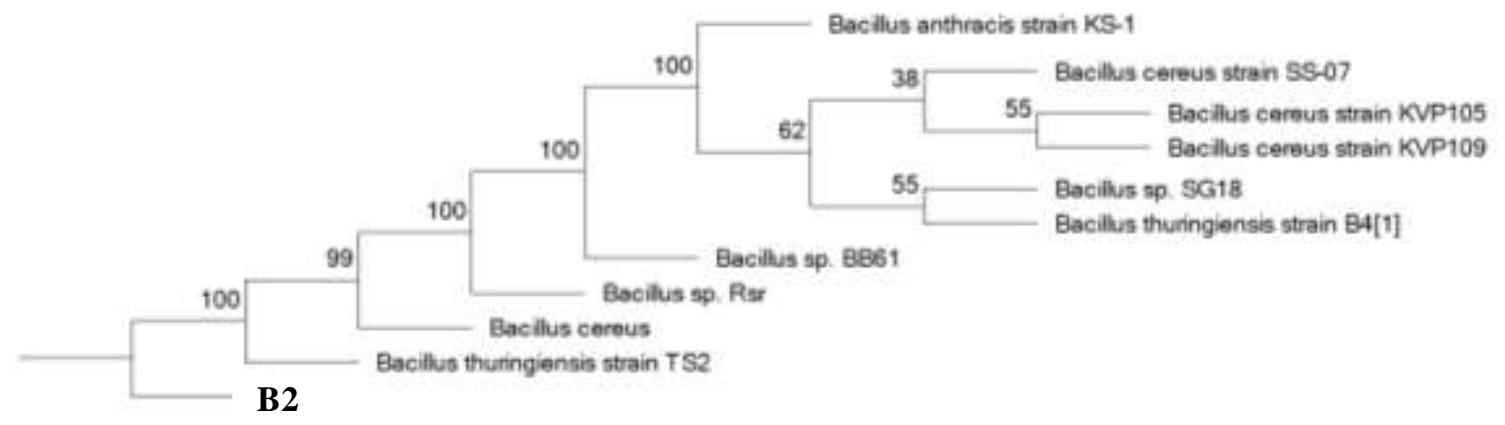

Table (3): Measuring total carbohydrates and total protein in the culture broth of two strains

\begin{tabular}{|l|l|l|}
\hline Sample Name & Total Protein / 1ml & Total Carbohydrates/ 1ml \\
\hline Bacillus cereus & $2.56 \mu \mathrm{g}$ & $0.524 \mu \mathrm{g}$ \\
\hline Bacillus thuringiensis & $1.78 \mu \mathrm{g}$ & $0.321 \mu \mathrm{g}$ \\
\hline
\end{tabular}


Fig (10): Amino acid compositions of B. cereus and B. thuringiensis bioflocculant soluble protein by $\mu \mathrm{g} / \mathrm{ml}$ with different concentration .

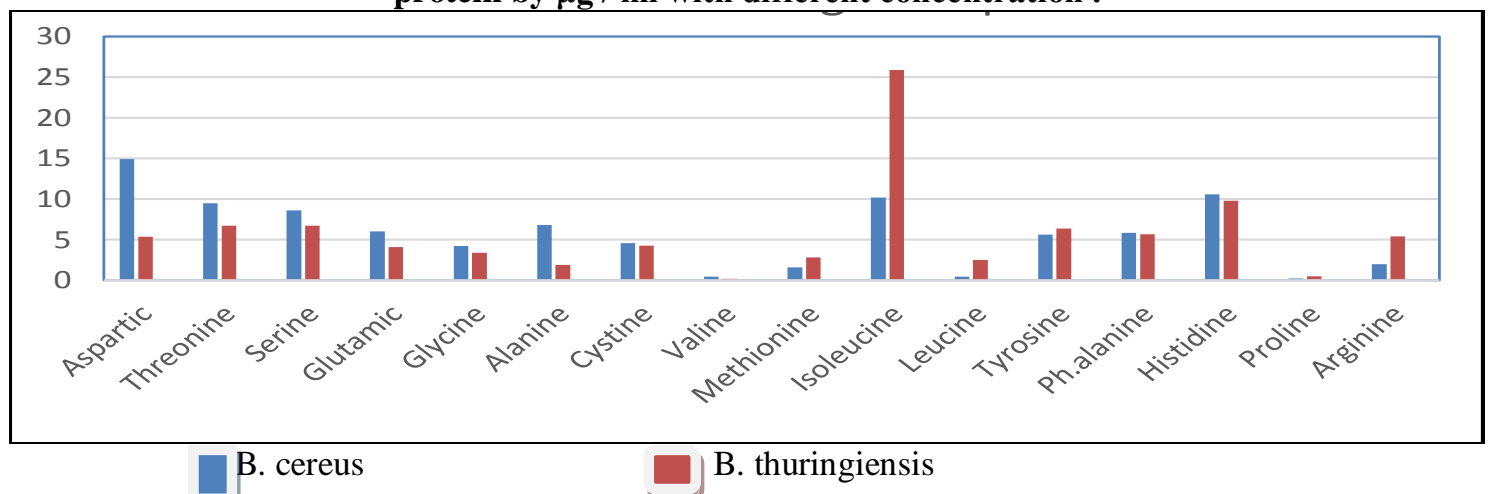

Table. (4): Comparison between water treated with Aluminum sulfate and water treated with investigated bacterial bioflocculants:

\begin{tabular}{|c|c|c|c|c|c|}
\hline Type of analysis & Raw water & $\begin{array}{l}\text { Water treated } \\
\text { with } \mathrm{Al}_{2}\left(\mathrm{SO}_{4}\right)_{3}\end{array}$ & $\begin{array}{l}\text { Water treated with } \\
\text { bioflocculant of } \\
\text { Bacillus cereus }\end{array}$ & $\begin{array}{l}\text { Water treated with } \\
\text { bioflocculant of } \\
\text { Bacillus thuringiensis }\end{array}$ & $\begin{array}{l}\text { Maximum limits } \\
\text { in Tap water }\end{array}$ \\
\hline $\begin{array}{l}\text { Turbidity\% } \\
\text { Flocculating } \\
\text { activity \% }\end{array}$ & $\begin{array}{l}13.5(100 \% \\
0 \% \\
0\end{array}$ & $\begin{array}{l}1.7 \\
12.6 \% \\
87.4 \% \\
\end{array}$ & $\begin{array}{l}3.2 \\
23.7 \% \\
76.3 \% \\
\end{array}$ & $\begin{array}{l}3.4 \\
25.0 \% \\
75 \% \\
\end{array}$ & $\begin{array}{l}1.0 \mathrm{NT} \\
7.4 \% \\
92.6 \% \\
\end{array}$ \\
\hline Temperature ${ }^{\circ} \mathrm{C}$ & 21 & 22.5 & 21.4 & 21.4 & $22 \circ \mathrm{C}$ \\
\hline pH & 8.25 & 7.2 & 7.2 & 7.2 & $6.5-8.5$ \\
\hline TDS & 259 & 269 & 262 & 264 & $1000 \mathrm{mg} / \mathrm{L}$ \\
\hline Ammonia & 0.05 & UDL & UDL & UDL & $0.5 \mathrm{mg} / \mathrm{L}$ \\
\hline Nitrate & 0.001 & UDL & UDL & UDL & $45 \mathrm{mg} / \mathrm{L}$ \\
\hline Nitrite & UDL & UDL & UDL & UDL & $0.2 \mathrm{mg} / \mathrm{L}$ \\
\hline Total alkalinity & 142 & 120 & 120 & 118 & $\mathrm{mg} / \mathrm{L}$ \\
\hline Total hardness & 126 & 128 & 126 & 126 & $500 \mathrm{mg} / \mathrm{L}$ \\
\hline Calcium & 30 & 30 & 30 & 30 & $350 \mathrm{mg} / \mathrm{L}$ \\
\hline Magnesium & 12 & 12 & 12 & 12 & $150 \mathrm{mg} / \mathrm{L}$ \\
\hline Chloride & 27 & 31 & 27 & 28 & $250 \mathrm{mg} / \mathrm{L}$ \\
\hline Sulfate & 24 & 35 & 25 & 25 & $250 \mathrm{mg} / \mathrm{L}$ \\
\hline Silica & 1.7 & 1.9 & 1.7 & 1.7 & $\mathrm{mg} / \mathrm{L}$ \\
\hline Phosphate & 0.005 & UDL & UDL & UDL & $\mathrm{mg} / \mathrm{L}$ \\
\hline Fluoride & 0.3 & 0.21 & 0.20 & 0.20 & $0.8 \mathrm{mg} / \mathrm{L}$ \\
\hline Ferrous & 0.15 & $\overline{\mathrm{UDL}}$ & $\overline{\text { UDL }}$ & UDL & $0.3 \mathrm{mg} / \mathrm{L}$ \\
\hline Manganese & UDL & UDL & UDL & UDL & $0.4 \mathrm{mg} / \mathrm{L}$ \\
\hline Aluminum & 0.24 & 0.19 & 0.15 & 0.18 & $0.2 \mathrm{mg} / \mathrm{L}$ \\
\hline Total Alga & 7000 & 18 & 27 & 27 & Unit/ $1 \mathrm{ml}$ \\
\hline $\begin{array}{ll}\text { Total } & \text { Coliform } \\
\text { bacteria } & \end{array}$ & +1600 & 1> & $1>$ & $1>$ & $1>$ unit/ $100 \mathrm{ml}$ \\
\hline $\begin{array}{l}\text { Total bacterial } \\
\text { count }\end{array}$ & 2500 & $50>$ & $50>$ & $50>$ & $50>$ unit/ $100 \mathrm{ml}$ \\
\hline $\begin{array}{l}\text { Microscopic } \\
\text { examination }\end{array}$ & $\begin{array}{l}\text { Warms \& } \\
\text { life protozoa }\end{array}$ & $\begin{array}{l}\text { Free from } \\
\text { Warms \& life } \\
\text { protozoa }\end{array}$ & $\begin{array}{l}\text { Free from Warms \& } \\
\text { life protozoa }\end{array}$ & $\begin{array}{l}\text { Free from Warms \& } \\
\text { life protozoa }\end{array}$ & $\begin{array}{l}\text { Free from Warms \& life } \\
\text { protozoa }\end{array}$ \\
\hline
\end{tabular}

NTU: National Turbidity Unit, TDS: Total dissolved salts, UDL: undetected limit .

5) Comparison between water treated with Aluminum sulfate and water treated with bacterial bioflocculants

The ability of B. cereus \& B. thuringiensis bioflocculant to flocculate various suspended particles in raw water was investigated and compared with the data obtained by using $\mathrm{Al}_{2}\left(\mathrm{SO}_{4}\right)_{3}$. It is clear from the data summarized from table (4) that the tested bioflocculants had obvious flocculating activity against all suspended particles beside their ability to minimize and remove the microbial and algal contaminations. $\mathrm{Al}_{2}\left(\mathrm{SO}_{4}\right)_{3}$. flocculating activity about $87.4 \%$, while two bacterial bioflocculants $75 \%$ and $76.3 \%$. 
6-Application of gold and silver nanoparticles conjugated with bacterial bioflocculants in water treatment:

(6-a) Characterization of silver and gold nanoparticles : In recent of first twenty century the use of

Fig. 11): UV-Vis spectrum of silver Nanoparticles show the w.v. of silver at $421 \mathrm{~nm}$ and gold at $527 \mathrm{~nm}$
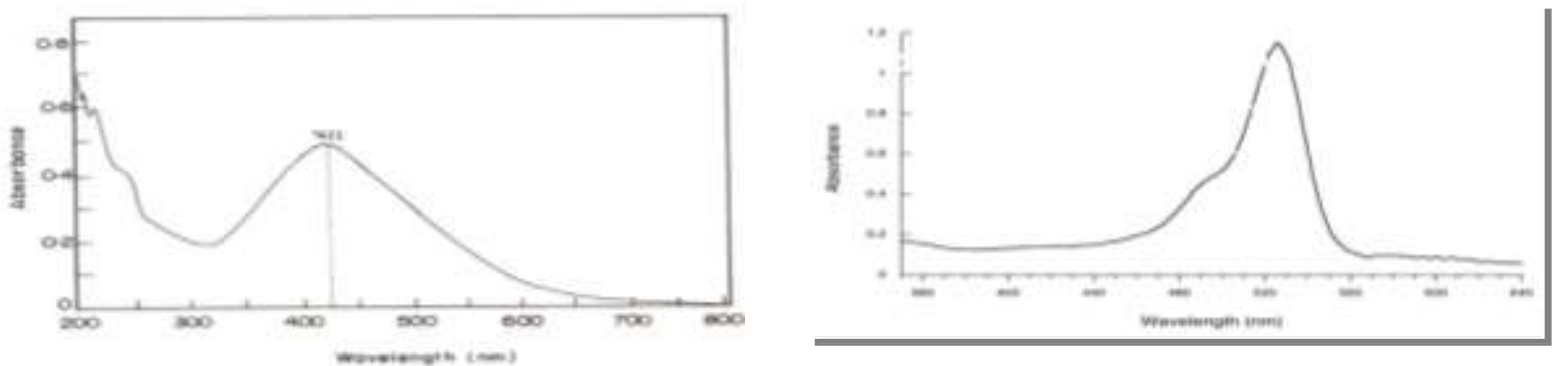

nanotechnology in the treatment of raw water was popularized, so in this research silver and gold nanoparticles were prepared in order to test its effectiveness in reducing the turbidity of raw water, also it has been uploaded to the bacterial bioflocculants

Fig (12 : Transmission electron microscopy (TEM) : ( magnification power 10.000 xs.)

(A)- images of silver nanoparticles with diameters of $30 \mathrm{~nm}$.

(B) images of gold nanoparticles: with diameters of $60 \mathrm{~nm}$.

(C) Images of Bacillus cereus bioflocculants with Silver nanoparticles trapping .

( D ) Images of Bacillus thuringiensis bioflocculants with Gold nanoparticles trapping .
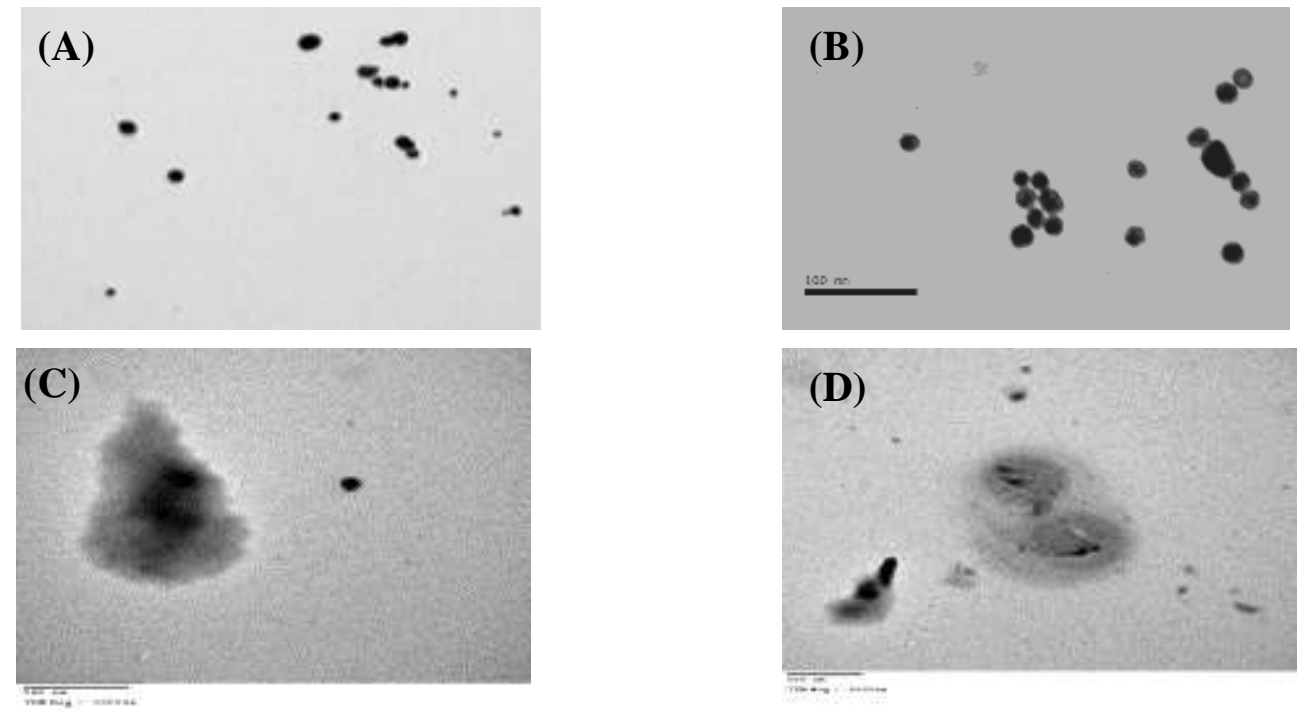

Table (5): Silver Nan-particles with bioflocculant of B. cereus \& B. thuringiensis and its effectiveness on raw water. $1 \mathrm{ml}$ contains $2.56 \mu \mathrm{g} / \mathrm{ml}$ flocculants.

\begin{tabular}{|c|c|c|c|c|c|c|c|c|c|}
\hline \multirow{4}{*}{$\begin{array}{l}\text { Concentrations of } \\
\text { silver nanoparticles } \\
\text { SNP ml/l } \\
1 \mathrm{ml} \\
\end{array}$} & \multirow{4}{*}{$\begin{array}{l}\text { Turbidity of } \\
\mathbf{H}_{2} \mathbf{O} \\
14.5 \\
\end{array}$} & \multicolumn{6}{|c|}{$\begin{array}{l}\text { Results of SNP } \\
\text { (bioflocculants activity \%) }\end{array}$} & \multicolumn{2}{|c|}{ Statistical analysis } \\
\hline & & \multicolumn{2}{|c|}{ SNP alone } & \multicolumn{2}{|c|}{$\mathrm{SNP}+$ B. cereus } & \multicolumn{2}{|c|}{$\begin{array}{l}\mathrm{SNP}+\mathrm{B} . \\
\text { thuringiensis }\end{array}$} & \multirow[t]{2}{*}{ Std.D. } & \multirow[t]{2}{*}{+ Std.E } \\
\hline & & \multicolumn{2}{|c|}{ Turbidity+ \% } & \multicolumn{2}{|c|}{ Turbidity+ \% } & \multicolumn{2}{|c|}{ Turbidity+ \% } & & \\
\hline & & 11 & $24.1 *$ & 9 & $38^{*}$ & 9.1 & $37.2 *$ & 3.550 & +1.123 \\
\hline 2 & & 8 & $45 * *$ & 7.1 & $51 * *$ & 7.2 & $50.3 * *$ & 1.11 & +0.011 \\
\hline 3 & & 3 & $79.3 * * *$ & 2.7 & $80.7 * * *$ & 2.9 & $80 * * *$ & 1.21 & +0.025 \\
\hline 4 & & 5.8 & $60 * * *$ & 5.3 & $63.4 * * *$ & 5.8 & $60 * * *$ & 1.7 & +0.02 \\
\hline 5 & & 7.3 & $49.6^{* * *}$ & 7 & $51.7 * *$ & 7 & $51.7 * *$ & 2.01 & +0.21 \\
\hline 6 & & 7.9 & $45.5^{* *}$ & 7.2 & $50.3^{* *}$ & 7.4 & $48.9 * *$ & 2.51 & +1.13 \\
\hline
\end{tabular}

* Non-significant change in comparing with control raw water $(\mathrm{P}>0.05)$.

** Significant change in comparing with raw water $(\mathrm{P}<0.05)$.

***Highly significant change in comparing with control raw water $(\mathrm{P}<0.0001)$ 
under study in order to increase its influence in reducing turbidity and show which the best treatment process for raw water as shown in Tables (5 and 6 ) and Figs (11\& 12). Using nanoparticles as raw water treatment was approximately similar to that obtained two bioflocculants FQ- $\mathrm{B}_{1}$ and FQ- $\mathrm{B}_{2}$ and the conjugation of nanoparticles with bioflocculants ranged from $(75.5 \%-80 \%)$. while $\left(\mathrm{Al}_{2}\left(\mathrm{SO}_{4}\right)_{3}\right.$ precipitation was $87.4 \%$. Also, the conjugation of nano-particles with bioflocculants about $80 \%$. Generally transmission electron microscopy TEM images of the nanoparticles irregular circular group or irrgular circular in linear shape, when conjugation with bioflocculants nanoparticles trapping and converted to a large sponge structure as a result of the interaction between bioflocculant and nano particles in both of two organisms cause unaffected of nanoparticles and become similar any metales treaed in raw water treatments by bioflocculant .This refered to high flocculating efficiency without addtion nanoparticles .

Table (6): Gold Nan-particles with bioflocculant of B. cereus \& B. thuringiensis and its effectiveness on raw water. $1 \mathrm{ml}$ contains $2.56 \mu \mathrm{g} / \mathrm{ml}$ flocculants .

\begin{tabular}{|c|c|c|c|c|c|c|c|c|c|}
\hline \multirow{3}{*}{$\begin{array}{l}\text { Concentrations } \\
\text { of Gold } \\
\text { nanoparticles } \\
\text { GNP ml/l }\end{array}$} & \multirow{3}{*}{$\begin{array}{l}\text { Turbidity of } \\
\mathrm{H}_{2} \mathrm{O}\end{array}$} & \multicolumn{6}{|c|}{$\begin{array}{l}\text { Results of GNP } \\
\text { (bioflocculants activity \%) }\end{array}$} & \multicolumn{2}{|c|}{ Statistical analysis } \\
\hline & & \multicolumn{2}{|c|}{ GNP alone } & \multicolumn{2}{|c|}{ GNP+ B. cereus } & \multicolumn{2}{|c|}{$\begin{array}{l}\text { GNP+B. } \\
\text { thuringiensis }\end{array}$} & \multirow[t]{2}{*}{ Std.D. } & \multirow[t]{2}{*}{ +Std.E. } \\
\hline & & \multicolumn{2}{|c|}{ Turbidity+ \% } & \multicolumn{2}{|c|}{ Turbidity+\% } & \multicolumn{2}{|c|}{ Turbidity+ \% } & & \\
\hline $1 \mathrm{ml}$ & 14.5 & 11.5 & $20.7 *$ & 9.4 & $35.2 *$ & 9.25 & $36.2^{*}$ & 2.41 & +1.12 \\
\hline 2 & & 8.7 & $40 * *$ & 7.3 & $49.6^{* *}$ & 7.21 & $50.2 * *$ & 1 & +0.012 \\
\hline 3 & & 3.5 & $75.9 * * *$ & 3 & $79.3 * * *$ & 3 & $79.3 * * *$ & 1.10 & +0.02 \\
\hline 4 & & 6.9 & $52.4 * * *$ & 6 & $58.6^{* * *}$ & 6 & $58.2 * * *$ & 1.56 & +0.026 \\
\hline 5 & & 7.7 & $46.9 * *$ & 7.1 & $51 * *$ & 7.3 & $49 * *$ & 2.11 & +0.81 \\
\hline 6 & & 8.2 & $43.4 * *$ & 7.7 & $46.9 * *$ & 7.8 & $46.2 * *$ & 2.43 & +1.10 \\
\hline
\end{tabular}

* Non-significant change in comparing with control raw water $(\mathrm{P}>0.05)$.

** Significant change in comparing with raw water $(\mathrm{P}<0.05)$.

***Highly significant change in comparing with control raw water $(\mathrm{P}<0.0001)$.

\section{Discussion}

Bioflocculants are essentially polymers produced by microorganisms during their growth .Bioflocculants have special advantages such as safety, strong effect, biodegradable and harmlessness towards humans and the environment (eco-friendly), so they may potentially be applied in drinking and waste water treatment. The organic flocculants, widely used in industrial fields, have been shown to be harmful to the environment and to be dangerous sources of pollution. This research aims to screening of twenty eight bacterial isolates flocculating producing substances. Two isolates were classified as Bacillus cereus and Bacillus thuringiensis based on 16S rRNA gene sequencing and its morphological, physiobiochemical characteristics and highly bioflocculant production . Maximum bioflocculant producing activity percent in water samples was affected by $\mathrm{pH}$ between (7- 8) and at temperature rang $30-40{ }^{\circ} \mathrm{C}$ and during growth period of strains from 72 to 96 hours. The results are in accordance with Zhang et al. (2007) and Xia et al. ( 2008), they reported that, the bioflocculant production is affected by many factors, such as the constituents of the culture medium and culture conditions. The effects of the key factors, like culture time, initial $\mathrm{pH}$ of the production medium, carbon source, nitrogen source, $\mathrm{C} / \mathrm{N}$ ratio, metal ion, ionic strength, culture temperature, shaking speed and inoculum size, on the flocculating activity of the bioflocculant were investigated with an aim to identify the cost-optimal culture conditions. The production of bioflocculant is influenced by metal ions in the culture medium, flocculating activity increased in the presence of $\mathrm{K}^{+}, \mathrm{Na}^{+}$or $\mathrm{Ca}^{2+}$. The flocculant production of Flavobacterium sp. was stimulated in the presence of $\mathrm{Ca}^{2+}, \mathrm{Mn}^{2+}$ and $\mathrm{Ba}^{2+}$ but was inhibited by $\mathrm{Mg}^{2+}$ (Buthelezi et al., 2009). Bioflocculants are polymers produced by microorganisms during their growth . It has been reported that all types of microbe's i.e; bacteria, fungi and algae produce flocculants with various properties . Different microorganisms are reported to produce variety of bioflocculants, e.g. R. erythropolis S1 and Nocardia armarae YK reported for protein bioflocculant. Glycoprotein bioflocculant production by B. muciligenous Shih et al. (2001) and Zhang et al. (2007) . Turbidity removal rate of raw water were observed a lower with increase in bioflocculant concentrations this is may be due to when the optimum concentration is exceeded, the aggregated particles can redisperse and this disturbs particle-settling ..Or this has been attributed to an increase in the repulsive energy between the flocculants and the microorganisms, which causes hindrance in floc. In general it is known that the genus of Bacillus includes a variety of industrially important species and has a history of safe use in both food and industry, these suggestions agreement with (Salehizadeh. \& Shojaosadati, 2003; Buthelezi et al., 2009 and Sekelwa et al., 2011). A bioflocculants named FQ-B1 and FQ$\mathrm{B} 2$, produced by Bacillus cereus and Bacillus thuringiensis respectively were precipitated by acetone, and then washed by ether, and the crude dialyzed at $4^{\circ} \mathrm{C}$ over night then vacuum-dried to obtain pure bioflocculan. The highest flocculating rates were achieved at biofloccul- ants dosage of $2.560 \mathrm{mg} / \mathrm{l}$. However, the depression of 
flocculating activity at high concentration of all bioflocculants is largely due to incomplete desperation of excess bioflocculant (Gao et al., 2006). Zhang, et al. (2007) and Xia et al. (2008) found approximately the same results effect on a bioflocculant TJ-F1 with high flocculating activity, produced by Proteus mirabilis TJ1 strain. It's known that Bacillus isolates made use of soluble starch and other nutrients and produces a polysaccharide or glycoprotein bioflocculant. Despite of that the starch can be modified into a flocculant through chemical reaction (Khalil and Ali, 2001).Generally Bacillus cereus and Bacillus thuringiensis produced an excellent biopolymer flocculant (glycoprotein). Chemical elemental analyses were achieved with UV Scan for analyses of the purified bioflocculant from broth culture (Glycoprotein's) and total carbohydrate content of bioflocculant soluble protein. Amino acid analysis was determined that there are 18 types of amino acids and Aspartic acid and Leucine were highly amino acid concentration respectively, this agreement with investrgation of Deng et al. (2003) and Sekelwa et al. (2011). However, if the major component of the bioflocculant is a glyco-protein its stability will depend on the relative components of protein and polysaccharide. For protein bioflocculant the amino and carboxyl groups are the effective group bioflocculation. A major condition for flocculation is the molecules of flocculants could adsorb onto the surface of particles (suspended solids in a River Nile). The charge of particles in water is negative. When bioflocculants were approaching particles in water, an attractive force must exceed the electrostatic repulsion force. Glycoprotein is a positive charge stimulates flocculating activity by neutralizing and stabilizing the residual charge of functional groups as binding distance is shortened Desouky et al. (2008).

In comparison between water treated with Aluminum sulfate $\left\{\mathrm{Al}_{2}\left(\mathrm{SO}_{4}\right)_{3}\right\}$ and with bacterial bioflocculants found three samples were free from Warms \& life protozoa, total alga and total coliform bacteria and flocculating activity of $\mathrm{Al}_{2}\left(\mathrm{SO}_{4}\right)_{3}$ was $87.4 \%$, but being voluminous, the alum. sludge's are gelatinous, acidic, and difficult to water and dispose in the environment. However, medical reports indicated that aluminum might induce Alzheimer's disease. While two bacterial bioflocculants $75 \%$ and $76.3 \%$ and thier potential of application in raw water treatment, owing to their effective bioflocculation effective and harmlessness towards humans and the environment. Two bacterial bioflocculants were able to reduce both turbidity and bacterial load from the contaminated river water to a varying degree, with higher bacterial load removal rate observed with increasing concentrations of the bioflocculants. While Faust and Aly (1998) showed that aluminum sulfate. was not effective in removing bacteria within the range of 5-10 ppm, with a removal of $99.7 \%$ achieved with $50 \mathrm{ppm}$, which is closer to the observation in most of studies. The high turbidity observed with the use of alum . as coagulant can be due to the production of aluminum hydroxide precipitate in water. Arezoo, 2002; Gao et al. (2006); Sekelwa et al. (2011) and Buthelezi et al. (2009) found that , compared to alum. which resulted in an acidic $\mathrm{pH}$ of 4-.14, this makes bacterial bioflocculant preferable in the practical terms as no further chemical addition is necessary in order to correct the $\mathrm{pH}$ of the finished water . Application of Silver $30 \mathrm{~nm} \&$ Gold $60 \mathrm{~nm}$ nanoparticles alone and in conjugation with bacterial bioflocculants (FQ-B1 and FQ-B2), exhibited efficient flocculation capabilities in the treatment of River Nile water. Using Gold and silver nanoparticles alone in raw water treatment was approximately similar to that obtained two bioflocculants FQ-B1and FQ-B2 and the conjugation of nanoparticles with bioflocculants ranged from (75 to 80\%). Transmission electron microscopy (TEM) observed images of the nanoparticles irregular circular in group or in linear shape, when conjugation with bioflocculants, nanoparticles trapping and converted to a large sponge structure, as a result of the interaction between bioflocculant and nano particles in both of two organisms cause unaffected of nanoparticles and become similar any metales treated in raw water treatments by bioflocculant, this refered to high flocculating efficiency without addtion nanoparticles .Desouky et al. (2008) and Hongyin (2013) obtained that silver nanoparticles in surface water, ground water, and brackish water are stable. However, in seawater conditions, AgNP tend to aggregate. Also showed that the antimicrobial activity of AgNP can be impaired by the presence of a humic substance and high concentrations of divalent cations. These results are helpful in explaining how discharged AgNP behave in natural aquatic systems as well as their environmental toxicological effects on naturally occurring microorganisms.

\section{Conclusion}

A bioflocculant-producing by strains Bacillus cereus and Bacillus thuringiensis an excellent biopolymer flocculant (glycoprotein's) with total protein was more than that of carbohydrate content. Also, bacterial bioflocculants FQ-B1and FQ-B2 had potential application about $76.5 \%$ in waste water treatment similar to gold and silver nanoparticles. When conjugation of bioflocculants with nanoparticles trapping and converted to a large sponge structure cause unaffected of nanoparticles this refered to high flocculating efficiency without addtion nanoparticles . At the same time, aluminum sulfate had highest flocculants activity $87.4 \%$, while residual aluminum concentrations in treated water can also impose health problems apart from the production of large amounts of sludge. Therefore, the use of high concentrations of alum . in the treatment of river water must be avoided. Thus making bioflocculant a better, wider and alternative in wastewater treatment and drinking water processing industry by B.cereus and B. thuringiensis as excellent biopolymer 
flocculant (glycoprotein), because of its effective flocculation and harmlessness towards humans and the environment .

\section{References}

[1]. Ammar A. Albalasmeh, Asmeret Asefaw Berhe, Teamrat A. Ghezzehei, (2013): A new method for rapid determination of carbohydrate and total carbon concentrations Using UV spectrophotometry. Carbohydrate Polymers 97: 253-261

[2]. Arezoo, C. (2002): The potential role of aluminum in Alzheimer's disease. Nephrol. Dial. Transplant. 17 (2), 17-20.

[3]. Bradford, M. M, 1976: A rapid and sensitive method for the quantization of protein utilizing the principle of the dye-protein binding. Anal.Biochem.72: $248-254$.

[4]. Buthelezi, S.P., Olaniran, A.O. and Pillay, B., (2009): Turbidity and microbial load removal from river water using bioflocculants from indigenous bacteria isolated from wastewater in South Africa. African Journal of Biotechnology Vol. 8 (14), pp. 3261-3266.

[5]. Chen, M. and Zhao, L. P., (2003): Biodiversity of bacterial isolates on three different media from coking wastewater treatment system. Acta Microbial.Sin.43: 367-371.

[6]. Claudio Jaime O., Esther Masih-Khan, Hongchang Tang, Jason Gonc,alves, Michael Voralia, Zhi Hua Li, Vincent Nadeem, Eva Cukerman, Ofelia Francisco-Pabalan, Choong Chin Liew, James R. Woodgett, and A. Keith Stewart, (2002): Amolecular compendium of genes expressed in multiple myeloma. The American Society of Hematology, 2174-2186.

[7]. Cowan, D.A and Steel's, K.O. (1977): Manual. for the identification. of medical bacteria . 2nd Edition.

[8]. Deng, S. B., Bai, R. B., Hu, X. M., et al. (2003): Characteristics of a bioflocculant produced by Bacillus mucilaginosus and its use in starch wastewater treatment.ApplMicrobiolBiotechnol60, 588-593.

[9]. Desouky, A.m., Abd El-Haleem, Roda, F.A., Thourya, A., Sidra, A. andFatima, H., (2008): Isolation and characterization of extracellular bioflocculant produced by bacteria isolated from Qatari Ecosystems. Polish J. Microbiol. 57(3): 231-239.

[10]. Farland A. D. Mc, C. L. Haynes, C. A. Mirkin, R. P. Van Duyne and H. A. Godwin, (2004): Citrate Synthesis of Gold Nanoparticles. J. Chem. Educ. 81: 544A.

[11]. Faust, S.D. and Aly, O.M.., (1998): Chemistry of water treatment $2^{\text {nd }}$ ed., CRC Press LLc, Lweis Publisher, New York. P. 581.

[12]. Gang Lian, Xiao Zhang, Haibin Si, Jun Wang, Deliang Cui, and Qilong Wang, (2013): Applied material and interfaces. Volume 5, Issue 24. Pages 12773-13484

[13]. Gao J., Hua-ying B., Ming-xiu X., Yuan-xia L., Qian L. and Yan-fen Z., (2006): Characterization of bioflocculant from newly isolated Vagococcus sp. W31. Journal of Zhejiang University Science B 7(3): 186-192.

[14]. Gregory, J (2006): Particles in water: properties and processes. Journal of scientific and Industrial research 57: 680-681..

[15]. Holt, J.; Krieg, N.; Sneath, P.; Staley, J. and Williams, S. (1994): Bergey's Manual of Determinative Bacteriology (9 edition) Williams and Wilkins, Baltimore.

[16]. Hongyin Zhang (2013): Doctor of philosophy in application of silver nanoparticles in drinking water purification,incivil and environmental engineering 2013

[17]. John C. Russ, 2010: Extending the unsharp mask image Processing filter. Materials Science and Engineering Dept. USA, pp.1-17.

[18]. Khalil, R. and Ali, A.A., 2001: Preparation and extraction of some cationic starch derivatives as flocculant. StarchlStaerke. 53: 8489.

[19]. Kumar, C.G., Joo, H.S., Kavali, R., Choi, J.W. and Chang, C.S., (2004): characterization of an extracellular biopolymer flocculant from a haloalkalophilic Bacillus isolates. World J. Micro. Biotech.,20(8): 837-843

[20]. Li, Y., He, N., Guan, H., Du, G., Chen, J., (2003). A polygalacturonic acidbioflocculant REA-11 produced by Corynebacteriumglutamicum: a proposed biosynthetic pathway and experimental confirmation. Appl.Microbiol. Biotechnol. 63, 200-206.

[21]. Liu W., Yuan H., Yang J. and Li B. (2009): Characterization of bioflocculants from biologically acrated filters backwashed sludge and its application in dying wastewater treatment. Bioresour. Technol. 100: 2629-2632.

[22]. Peiyong, Q. Tong, Z. and Cuixian, C., (2004): Microbial flocculant from natural soda. J. Americalchemi. Society.580-584.

[23]. Pradeep T.,and Anshup, (2009): Noble metal nanoparticles for water purification: A critical review. Thin Solid Films 517, 64416478

[24]. Rainey, F. A., Ward-Rainey, N., Kroppenstedt, R.m. and Stacke-Brantd, E., (1996): The genus Nocardiopsaceae fam. Nov. Int. J. Sys. Bacteriol. 46: 1088-1092.

[25]. Salehizadeh and Shojaosadati, (2001): Extracellular biopolymeric flocculants: recent trends and biotechnology importance. Biotechnol. Adv., 19(5): 371-385.

[26]. Salehizadeh H. and Shojaosadati SA., (2003): Removal of metal ions from aqueous solution by polysaccharide produced from Bacillus firmus. Water Research, 37: 4231-4235

[27]. Sambrook, J., Fritschi, E. F. and Maniatis, T., (1989): Molecular cloning: a laboratorymanual, Cold Spring Harbor Laboratory Press, New York.

[28]. Sekelwa C., Leonard V.M., Ademola O., Omobola O., Kim B., Shaun D. and Anthony I., (2011): Bioflocculant production by Virgibacillus sp. Rob isolated from the bottom sediment of algoe bay in Eastern Cape, South Africa. Molecules 16: 2431-2442.

[29]. Shih, I. L., Y. T. Van, L. C. Yeh, H. G. Lin, and Y. N. Chang, (2001):.Production of a biopolymer flocculant from Bacillus licheniformis and its flocculation properties. Bioresour. Technol. 78:267-372.

[30]. Sneath, P. (1986): Bergey's Manual of Systematic Bacteriology. $1^{\text {st }}$ ed., Vol. 2. William \& Wilkins, Baltimore.

[31]. Wu, J. Y., and H. F. Ye, (2007): Characterization and flocculating properties of an extracellular biopolymer produced from a Bacillus subtilis DYU1 isolate. Process Biochem.42:1114-1123.

[32]. Xia, S. A., Zhiqiang Zhang a, b., Xuejiang Wang a, Aming Yang a, Ling Chen a, Jianfu Zhao a, Didier Leonard b, Nicole JaffrezicRenault, (2008): Production and characterization of a bioflocculant by Proteus mirabilis TJ-1. Bioresource Technology 99: 65206527

[33]. Yoon, J.H., Cho, Y.G., Kang, S.S., Kim, S.B., Lee, S.T., Park, Y. H., (2000): Rodococcus koreensis sp. Nov. a 2, 4-dinitrophenoldegrading bacterium. Int. J. Sys. Bacteriol 50: 1193-1201.

[34]. Zhang, J., Liu, Z., Wang, S., Jiang, P., (2002): Characterization of abioflocculant produced by the marine myxobacterium Nannocystis sp. NU-2. Appl. Microbiol. Biotechnol. 59, 517-522.

[35]. Zhang, Z.Q., Lin, B., Xia, S.Q., Wang, X.J., Yang, A.M., (2007): Production and application of a bioflocculant by multiplemicroorganism consortia using brewery wastewater as carbon source. J. Environ. Sci.. China 19, 660-666.

[36]. Zhang, H., (2013). "Application of Silver Nanoparticles in Drinking Water Purification" 